\title{
Understanding the Entrepreneurial Process: a Dynamic Approach
}

\author{
Vânia Maria Jorge Nassif * \\ E-mail address: vania.nassif@uol.com.br \\ Universidade Presbiteriana Mackenzie and FACCAMP - Master Program Administration \\ São Paulo and Campo Limpo Paulista, SP, Brazil.
}

\section{Alexandre Nabil Ghobril \\ E-mail address: ghobril@uol.com.br Universidade Presbiteriana Mackenzie São Paulo, SP, Brazil.}

\section{Newton Siqueira da Silva}

E-mail address: newton.silva@ncgconsultoria.com.br

Universidade de São Paulo

São Paulo, SP, Brazil.

\begin{abstract}
There is considerable predominance in the adoption of perspectives based on characteristics in research into entrepreneurship. However, most studies describe the entrepreneur from a static or snapshot approach; very few adopt a dynamic perspective. The aim of this study is to contribute to the enhancement of knowledge concerning entrepreneurial process dynamics through an understanding of the values, characteristics and actions of the entrepreneur over time. By focusing on personal attributes, we have developed a framework that shows the importance of affective and cognitive aspects of entrepreneurs and the way that they evolve during the development of their business.
\end{abstract}

Key words: entrepreneurship; entrepreneurial process; entrepreneur characteristics; dynamic approach.

Received 08 April 2009; received in revised form 08 July 2009.

Copyright (C) 2010 Brazilian Administration Review. All rights reserved, including rights for translation. Parts of this work may be quoted without prior knowledge on the condition that the source is identified.

* Corresponding author: Vânia Maria Jorge Nassif

Rua Major Sertório, 733, Vila Buarque, São Paulo, SP, 01222-010, Brazil. 


\section{INTRODUCTION}

Small businesses have become increasingly important in driving economic and social development in the world. Bygrave (2004) points out that from 1990 to 1994 American small businesses, those with less than 100 employees, generated between seven and eight million new jobs, while large-scale businesses, over the same period, eliminated 3.6 million jobs. In addition to being a major source of job creation, small businesses are also a powerful source for innovation. In the United States, they employ 39\% of all high tech workers and produce 14 times more patents per employee than large businesses. In that country, small businesses are responsible for around $40 \%$ of the Gross National Product [GNP] and employ 53\% of the work force in the private sector. They are responsible for creating $75 \%$ of new jobs; furthermore, $67 \%$ of young people enter the job market via small businesses.

According to a survey by the Instituto Brasileiro de Geografia e Estatística [IBGE] (as quoted in Serviço Brasileiro de Apoio às Micro e Pequenas Empresas [SEBRAE], 2005a), micro and small businesses have also become increasingly important to the Brazilian economy. Combined, micro and small businesses are responsible for $99.2 \%$ of the total number of businesses, $57.2 \%$ of the total jobs, and $26.0 \%$ of salary mass. As a result of the expressive increase in the number of jobs generated over two years by these businesses, there was a real increase in salary mass of $57.3 \%$ in micro businesses and $37.9 \%$ in small businesses.

Data from SEBRAE (2005b) show that micro and small businesses generated $42 \%$ of the revenue produced in the Brazilian industrial sector, accounting for $21 \%$ of the GNP.

However, a large number of ventures do not achieve success. One of the main reasons for the high mortality rate is the entrepreneurs' lack of ability to develop and manage their businesses (SEBRAE, 2005c).

This underpins the importance of understanding the dynamics of entrepreneurship and the role of the entrepreneur as the main actor in this process.

In research into understanding the entrepreneur and entrepreneurship, Sadler-Smith, Hampson, Chaston and Badger (2003) point out that there is a strong predominance in the adoption of perspectives based on characteristics, while McClelland et al. (as cited in Filion, 1999) emphasize that the field is still dominated by positivist-functionalists and that there is an urgent need for new perspectives to understand who entrepreneurs are and what it is that they do.

Indeed, the predominance of the characteristic-based perspectives can be observed, among others, in the studies of:

. Miner (1998), which aimed to identify entrepreneur types;

. Filion (2000), which targeted the differences between the entrepreneurial process and the management process;

. Cruz, Forner and Libermann (2003), which sought to identify the characteristics of Brazilian entrepreneurs;

. Thompson (2004), which outlined a new framework for identifying entrepreneurs;

- Nassif, Ghobril, Castilho, Silva and Guardani (2004), which proposed an integrative scheme to understand the competencies of the entrepreneur from the perspective that categorizes the entrepreneur's characteristics in the affective or cognitive dimensions;

- Lenzi, Venturi and Dutra (2005), which sought to identify the most common types and characteristics of Brazilian small business entrepreneurs; 
. Mallmann, Borba and Ruppenthal (2005), which developed research to evaluate the typology of entrepreneurs;

. Barros and Moreira (2005), which focused on the behavior of the entrepreneur and its implications in the tourism sector of Brazil;

. Lindsay (2005), which used the cultural dimension and entrepreneurial attitude constructs to develop a model to explain how culture influences the indigenous entrepreneur's attitude toward new venture creation and development and associated entrepreneurial behavior;

. Petrakis (2005), which focused on ex ante and ex post entrepreneurial attitudes towards risk;

. Arenius and Minniti (2005), which investigated what variables are significantly correlated with an individual's decision to become an entrepreneur; and

. Fernandes and Santos (2008), which examined the role of entrepreneurship in business performance.

However, we can see that these and other studies sought to describe the entrepreneur from a static or snapshot approach.

Accepting the hypothesis that entrepreneurs change over time, Westhead, Ucbasaran and Wright (2005) extended Reuber and Fischer's conceptual framework to take into account differences between inexperienced novice entrepreneurs (i.e., individuals with no prior private business ownership experience) and experienced serial and portfolio entrepreneurs.

Bygrave (2004), in his turn, adopts a dynamic perspective in proposing a model that highlights the personal attributes and environmental factors that influence the venture at each stage.

The model set forth by Bygrave (2004) is based on Moore's model. Bygrave's model raises issues that suggest the need for research that would incorporate the dynamic perspective in the understanding of the entrepreneur and entrepreneurship. Adopting this perspective, we have developed a framework in this study to contribute to the construction of an explanatory model of the dynamics of the entrepreneurial process through an understanding of the values, characteristics and actions of the entrepreneur.

\section{The ENTRepreneurial Process}

Based on Moore's model, Bygrave (2004) presents the entrepreneurial process as a set of stages and events that follow one another. These stages are: the idea or conception of the business, the event that triggers the operations, implementation and growth.

In his model of the entrepreneurial process (Figure 1), Bygrave (2004) highlights the critical factors that drive the development of the business at each stage. According to Bygrave (2004, p. 5), "as with most human behavior, entrepreneurial traits are shaped by personal attributes and environment". 


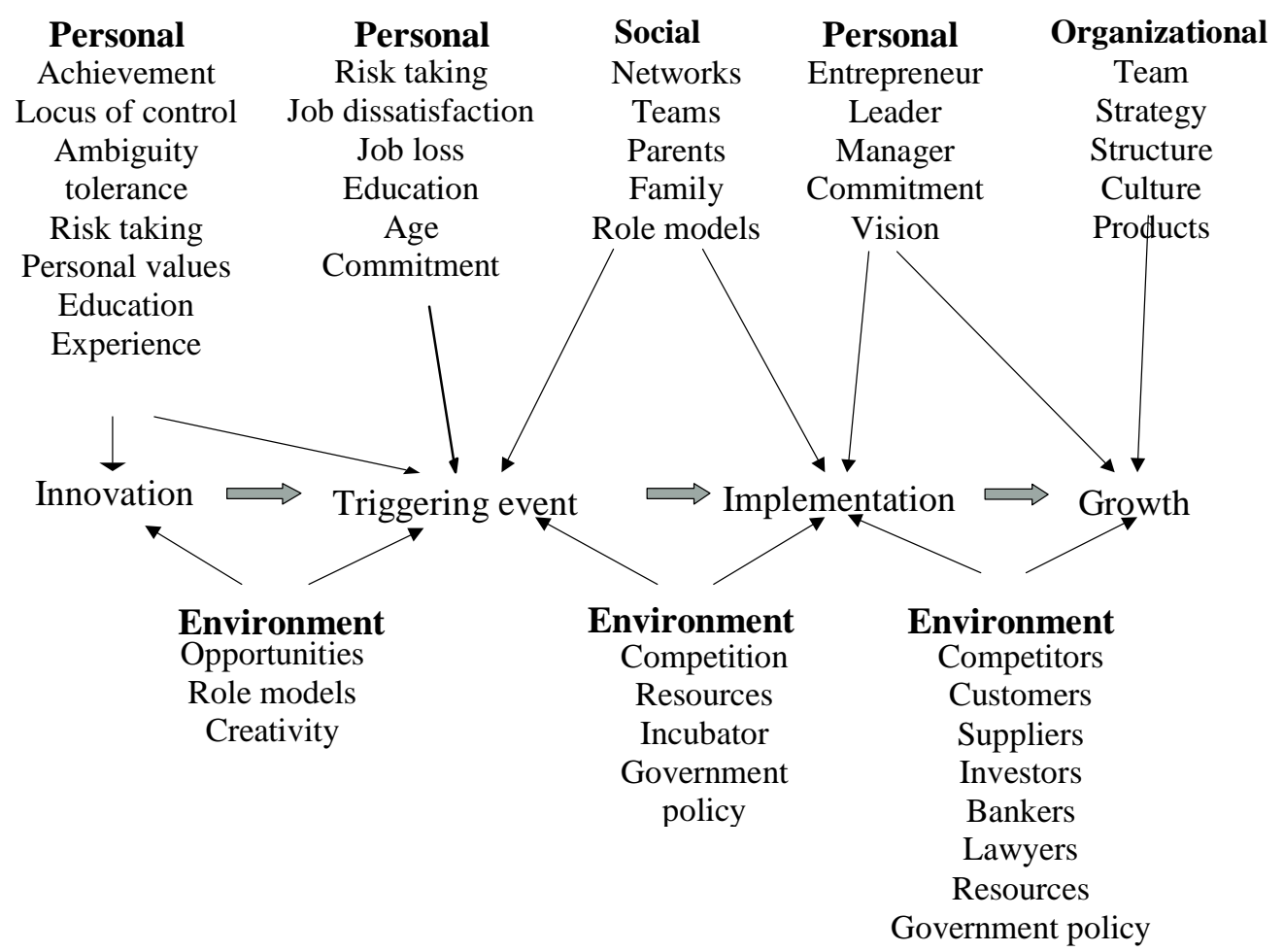

Figure 1: Model of the Entrepreneurial Process

Source: Bygrave, W. D. (2004). The entrepreneurial process. In W. D. Bygrave \& A. Zacharakis (Eds.). The portable MBA in entrepreneurship (p. 3). Hoboken, NJ: John Wiley \& Sons.

Personal attributes are the characteristics of entrepreneurs that make them different from nonentrepreneurs. This theme has been fertile in research into entrepreneurship.

In looking to contribute to the identification and understanding of the behavior that may lead an entrepreneur to success, studies by McClelland (1965) set forth the following entrepreneurial characteristics: seeking opportunities and initiative, identification of opportunities, ability to react to frustration and 'stressing' situations, demand for quality and efficiency, commitment, establishing goals, planning and systematic monitoring, persuasion and a network of contacts, and independence. Timmons (1978) agrees that certain personal attributes, such as the need for realization, a propensity for taking calculated risks, and control locus (an intense desire to be in control of one's own destiny), are observed in the majority of successful entrepreneurs.

The importance of human factors is also reinforced by Beugelsdijk and Noorderhaven (2005), who conducted empirical research with 14,846 individuals in Finland and showed that entrepreneurs differ from the general population, and with wage- and salary earners, in a number of characteristics, particularly in individual responsibility and effort.

Filion (1999) has stated that the literature often points out that entrepreneurs actively strive to achieve goals, and that they develop tenacity and creativity, as well as the ability to detect opportunities and that they are agents for change, that is, they do new and different things.

Salim (2004), in his turn, emphasizes that the successful entrepreneur has the following characteristics: takes risks, identifies opportunities, understands the business field, is organized, makes correct decisions, possesses leadership skills, is dynamic, is independent, is optimistic and has good business sense. Dornelas (2001) adds to these attributes dedication, seeking wealth, planning, value to society and a forward-looking vision. 
Clercq and Arenius (2003) state that there is a relation between human capital, i.e., the experience and understanding of the entrepreneur, and the success of the entrepreneurial activity, so that those who are best educated and invest more resources in improving their abilities are more apt to reap the benefits through their entrepreneurial activities.

Bygrave (2004, p. 5), on the other hand, affirms: "We know that there is no neat set of behavioral attributes that allow us to separate entrepreneurs from non-entrepreneurs". Meanwhile, he emphasizes that "it does appear that entrepreneurs have a higher locus of control than non-entrepreneurs, which means that they have a higher desire to be in control of their on fate". Instead of using psychological terms to describe the entrepreneur's characteristics, Bygrave (2004) uses a set of everyday words, which he named "The 10 Ds" (Table 1).

Table 1:

The 10 Ds

\begin{tabular}{ll}
\hline Dream & Entrepreneurs have a vision of what the future could be like for them and their \\
businesses. And, more important, they have the ability to implement their dreams. \\
Decisiveness \\
fhey do not procrastinate. They make decisions swiftly. There swiftness is a key \\
factor in their success. \\
Once they decide on a course of action, they implement it as quickly as possible. \\
Doers \\
They implement their ventures with total commitment. They seldom give up, even \\
when confronted by obstacles that seem insurmountable \\
They are totally dedicated to their business, sometimes at considerable cost to their \\
relationships with their friends and families. They work tirelessly. Twelve-hour days \\
and seven-day work weeks are not uncommon when an entrepreneur is striving to \\
get a business off the ground. \\
Entrepreneurs love what they do. It is that love that sustains them when the going \\
gets tough. And it is love of their product or service that makes them so effective at \\
selling it. \\
It is said that the devil resides in the details. That is never more true than when \\
starting and growing a business. The entrepreneur must be on top of the critical \\
details. \\
They want to be in charge of their own destiny rather than dependent on an \\
employer. \\
Getting rich is not the prime motivator of entrepreneurs. Money is more a measure \\
of their success. They assume that if they are successful they will be rewarded. \\
Entrepreneurs distribute the ownership of their businesses with key employees \\
who are critical to the success of the business. \\
Dellars
\end{tabular}

Note. Source: Bygrave, W. D. (2004). The entrepreneurial process. In W. D. Bygrave \& A. Zacharakis (Eds.). The portable MBA in entrepreneurship (p. 6).. Hoboken, NJ: John Wiley \& Sons.

Referring to environmental factors, Bygrave (2004) observes they are the external influences surrounding the beginning of the business and its development. He underlines the influence the local environment has on the willingness of the entrepreneur to open a business. He refers to Silicon Valley, where a set of favorable conditions, such as support from public policies, proximity to universities, access to technology and availability of financial resources combine to make this a good location for new ventures.

Environmental factors also include sociological factors such as: role models, family responsibilities, the trade-off between the experience that comes with age and the optimism and energy of youth, and contacts (a network of personal relationships). 
Concerning role models, Bygrave (2004, p. 7) emphasizes that they "are very important because knowing successful entrepreneurs makes the act of becoming one yourself seem much more credible".

Chay (1993) also identifies sociological factors as: family culture, network of personal relationships, past experiences, parents and role models.

Bygrave (2004) states that environmental factors interact with personal characteristics to increase the tendency toward opening one’s own business.

This model shows some factors connected to personal attributes in the idea generation stage: achievement, the entrepreneur's control locus, ambiguity tolerance, risk taking, personal values, education and experience. Other factors connected to personal attributes, such as job dissatisfaction, age and loss of job combine with sociological and environmental factors to trigger the decision to begin the venture.

In the succeeding stages of the business, from implementation to full organizational development in the growth stage, other personal attributes become important. These are: vision, leadership, entrepreneurial spirit, management ability and commitment.

The model suggests an evolving dynamic in the attributes of the entrepreneurs: behavioral profiles change and additional abilities develop as the organization grows in size and complexity. As such, it describes an aggregate vision of the dynamics of the entrepreneurial process, showing the shifting importance given to personal, sociological and environmental attributes throughout the evolution of the business. The model is coherent to life-cycle theory (Adizes, 1990; Churchill \& Lewis, 1983; Greiner, 1998; Kelley \& Marram, 2004), whose approach considers that planning actions occur in forward stages.

Bygrave (2004) makes no reference to personal attributes in terms of affective and cognitive aspects as is suggested by Gimenez (2000), Mitchell et al. (2002), Ucbasaran, Westhead and Whright (2001), and Nassif et al. (2004).

Another perspective is focused on the particular influence that certain industries have on the development of new businesses. According to Porter (1980), the competitive forces present in certain economy sectors such as industry growth, concentration, rivalry and entry barriers, make them more attractive than others.

\section{THE INTEgrative Diagram FOR UNDERSTANDING THE COMPETENCIES OF THE ENTREPRENEUR}

Based on the professional trajectories of highly successful entrepreneurs, Nassif et al. (2004) developed a diagram that presents two dimensions to accommodate the competencies extracted from empirical research: the affective and cognitive dimensions. They also identified other variables, which have been categorized as environment, individual values and results. This diagram can be seen in Figure 2. 


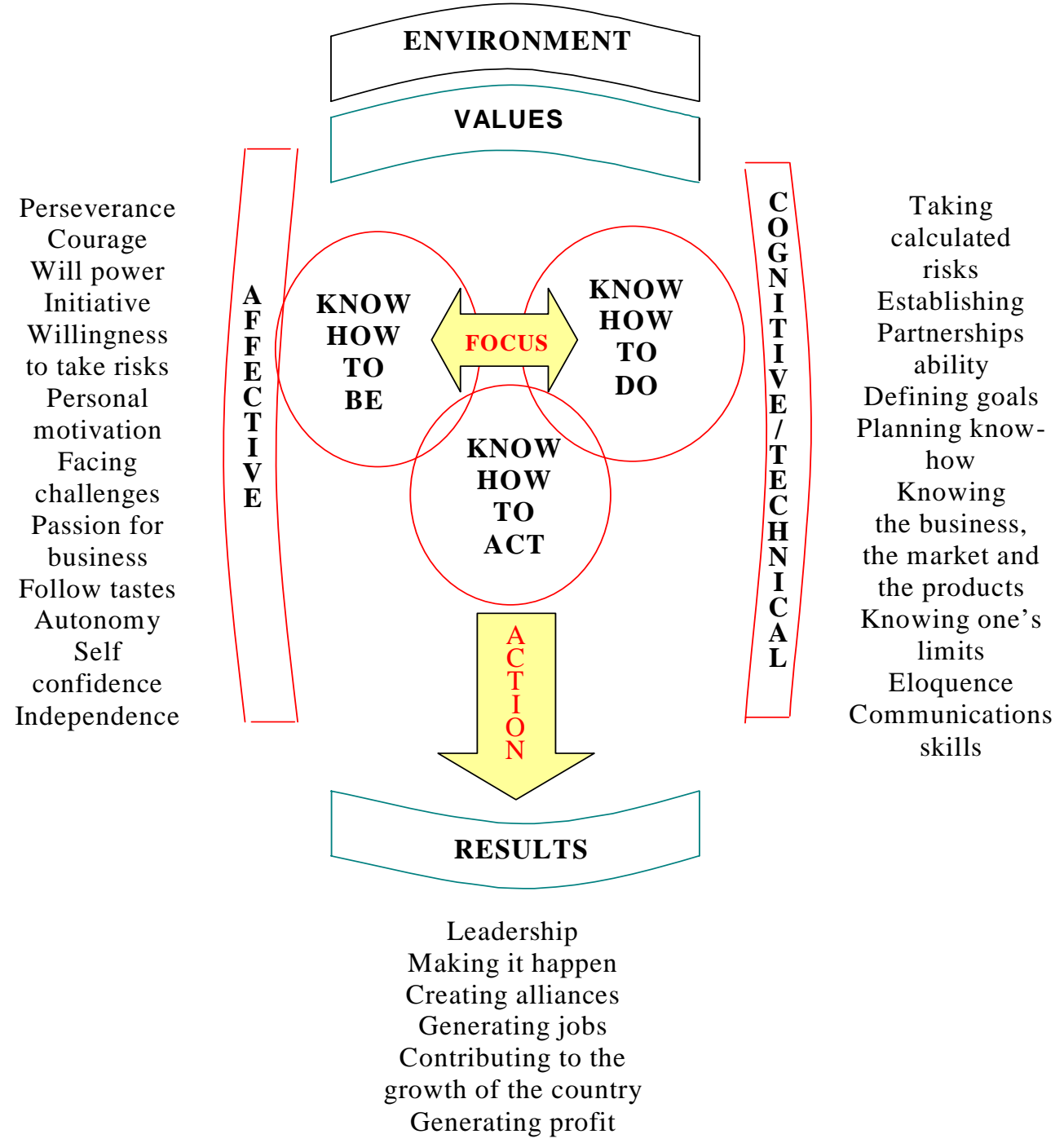

Figure 2: Integrative Diagram for Understanding the Competencies of the Entrepreneur Source: Nassif, V. M. J., Ghobril, A. N., Castilho, A. F., Silva, N. S., \& Guardani, F. R. (2004, setembro). Contribuição para o entendimento das competências do empreendedor: a derivação de um esquema a partir de relatos de trajetórias empresariais em pequenas empresas (p. 641). Anais do Encontro Nacional da Associação Nacional de Pós-Graduação e Pesquisa em Administração, Curitiba, PR, Brazil..

In their research, the authors verified that:

. Despite being fragmented in the theory on entrepreneurship, the affective and cognitive dimensions are not dissociable in practice;

- The affective aspects appear with greater intensity and frequency in field research into entrepreneurship, despite a tendency in the literature on this subject to value the cognitive aspects more highly;

. In the literature dealing with entrepreneurship, there is a strong emphasis on knowing how to do and not on knowing how to act. However, the research shows the importance of the person and his/her trajectory, intentions, world vision, values, beliefs... that is, on knowing how to be;

. As such, the integration and harmonization of the affective and cognitive dimensions becomes necessary because treating them separately can generate unsatisfactory results. 
The diagram developed by Nassif et al. (2004) contributes to the understanding of the entrepreneurs by categorizing their characteristics in dimensions that are related to affectivity and cognition. These dimensions constitute the pillars of the author's diagram, which also frames a static perspective.

\section{The Conception of the Entrepreneurial Process Dynamics Framework}

In order to better portray the entrepreneurial process from a dynamic perspective, we have proposed a framework that contemplates the temporal dimension and incorporates the changes in affective and cognitive aspects, values and environment over time.

\section{Environment and Affective and Cognitive Aspects}

Gersick (1997) states that there are two perspectives to explain how organizations and the behavior of the entrepreneur change over time. The first focuses on the external, social and economic forces on the organizations. This perspective incorporates institutional theories (Mayer, Davis, \& Schoorman, 1995), and dependence on resources and ecology (Hannan \& Freeman, 1989). It considers that the environmental factors are determinants imposing limitations on the reaction power of the organizations. According to this perspective, the role of leadership is basically reactive, and there is no specific sequence that can be applied to the course of internal development for all companies.

The other perspective is based on the organizational life-cycle models, which consider that companies change in a sequence of predictable stages, partly motivated by internal environmental conditions, but mainly due to complex maturation factors within the organization. The companies are treated as biological organisms: they are born, they grow, they mature, and they renovate when necessary to avoid declining and death. Authors such as Kelley and Marram (2004), Greiner (1998), Adizes (1990), and Churchill and Lewis (1983) present different developmental models for small businesses, following the logical evolution of the stages during their life-cycle.

While there is a consensus among researchers that the environment influences organizational development, the internal perspective suggests that the entrepreneur assumes a more active than reactive role in the development and success of the venture. It also considers that the affective and cognitive abilities of entrepreneurs evolve over time, allowing them to face hostile environments, independent of barriers, lack of resources or any other challenge that may arise along the way. We have adopted this perspective in our framework.

\section{Values and Affective and Cognitive Aspects}

Studies in different areas of the human and social sciences have contributed to enhancing the understanding of entrepreneurial behavior and the phenomenon of entrepreneurship. Schumpeter (1984) was the precursor in adopting an economic perspective towards entrepreneurship, attributing to the entrepreneur the role of driving agent in economic development and growth.

Other authors have utilized Psychology to understand the different dimensions of the entrepreneur, focusing on aspects such as the need for realization, autonomy, aggressiveness, power, recognition, innovation and independence (Hornaday \& Aboud, 1971), as well as the personality of the entrepreneur (Miner, 1998). Despite the growing interest in the subject, some conceptual models are still in the early stages of development, given the precariousness of universally accepted concepts and research methods (Brazeal \& Herbert, 1999).

Among the contributions from Psychology, a line of research stands out that is based on the social theory of cognition and the behavioral theory of decision-making. It seeks to explain the influence of the cognitive processes of the entrepreneur. The research into social cognition examines how people 
see the world, while the behavioral theory of decision-making uses normative models to address imperfections in the human decision-making processes (Tenbrunsel, Galvin, Neale, \& Bazerman, 2004).

Referring specifically to the use of cognitive structures in understanding the entrepreneur, Gimenez (2000) evaluates their importance, at the time when the entrepreneur is choosing a competitive strategy for his/her business, and builds the notion of cognitive styles as important predictors of strategic choice standards.

Using the term human capital to designate the cognitive characteristics of entrepreneurs, Álvares and Besunitz (as cited in Ucbasaran et al., 2001) assert that work and accumulated habits may have a strong effect, whether positive or negative, on productivity (Becker, as cited in Ucbasaran et al., 2001).

In referring to entrepreneurial cognition, Mitchell et al. (2002) allude to it as the structure of understanding that people use to evaluate and judge opportunities for decision-making, creation and growth in ventures. They cite a research into entrepreneurial cognition that demonstrates how the entrepreneur uses simplified mental models to unite pieces and connect information that helps to identify and develop new products or services, as well as to gather the necessary resources to build and grow a business. These authors state that there is a need for more in-depth studies in this field because corporate thinking and questions of perception developed by cognitive psychology have sought to understand and take part in research into entrepreneurship.

In a similar way, Bastos and Borges-Andrade (2004) analyze questions related to the cognition and action of social actors and state that organizations deal with environments that are arranged based on interpretations that people produce.

Machado-da-Silva and Fonseca (1999), in turn, point out that this subjective conception of the environment implies the possibility that it may be perceived in different ways. This opens perspectives for consideration and makes the actors dependent on their interpretive diagrams, bringing a collection of ideas, values, and beliefs that may propitiate order and coherence in the structures and systems in an organization.

In addition to stressing the cognitive aspects, Psychology also emphasizes the importance and value of affective aspects and emotions in organizational studies. Fineman (2001) asserts that organizational researchers have lingered in incorporating affective and emotional aspects into their considerations. He underlines, however, that there are studies that deal with the feelings that awaken passion, anguish, joy, boredom etc., and reinforces the idea that discussing emotions in the context of the organizations is part of the quotidian.

While Psychology discusses the non-dissociable cognitive and affective aspects, we found no research into entrepreneurship that included both.

Personal values are important factors when it comes to understanding the affective and cognitive aspects and the competencies (Elizur, Borg, Hunt, \& Beck, 1991). They are strongly influenced by family, education and religion, as normative standards utilized by a person to judge and select between alternative behavior models. These values are also considered the objectives in a desirable transitory situation, at different levels of importance that serve as a guide in each person's life. Schwartz (1994) and Schwartz and Sagiv (1995) state that values are also criteria that contribute to the evaluation of a person's actions.

Rokeach (1973) confirms through his studies that values have different levels of importance and vary from person to person. Despite being less numerous than attitudes and beliefs, they are more abstract and constant over time.

If, on the one hand, these values contain affective components that stimulate a person's reaction to defend them, on the other hand, when integrated with the cognitive aspects, they are stronger and 
determine personal attitudes and behaviors. Due to this, our framework has incorporated the values in the affective and cognitive aspects in order to understand the entrepreneurial process dynamics.

\section{Discussion}

This study aims to contribute to the understanding of the dynamics of the entrepreneurial process through the entrepreneur's values, characteristics and actions over time. The proposal is a response to the inability of existing models to adequately describe the dynamics of the entrepreneurial process.

Based on Moore's model, Bygrave (2004) presented a framework that highlights the critical factors that drive venture development at each stage. Inspired by this framework, we have developed a dynamic approach that focuses on the personal attributes.

It is important to make clear that this approach is applicable to all kinds of organizations, even those that are not classified as entrepreneurial ventures, which have three essential characteristics: innovation, potential for growth and clear strategic objectives as defined by Wickhman (2004 as cited in Duobiené, Gavenas, Anskaitis, \& Pundziene, 2007).

Reports of entrepreneurs extracted from empirical research (Nassif et al., 2004) show a predominance of affective aspects, such as perseverance, courage, personal motivation, acceptance of risks, optimism etc. at the beginning of the venture, especially in the business conception phase, which Bygrave (2004) calls innovation. In addition, Carvalho, Machado, Silva, Souza, and Ghobril (2006) assert that entrepreneurs give more importance to affective attributes at the beginning of the venture, and progressively emphasize the cognitive aspects.

However, it is important to emphasize that the aforementioned works were done in a specific environment: Brazil. Nevertheless, we believe that cultural, sociopolitical and economic factors should influence the importance of cognitive and affective aspects over time.

Delmar and Shane (2002) state that there are two different types of activities in the start-up process, which are: planning activities to establish the new venture and to signal cognitive legitimacy to outside stakeholders; and operation activities for the purpose of establishing the new venture in the market. Developing longitudinal research in Sweden, the authors conclude that activities related to planning and creating legitimacy reduces the probability of disbanding and increases the probability of establishing the venture. We believe that cultural features and the availability of financial and other resources anticipate the need for planning.

In view of this variation in the importance of the affective and cognitive aspects for the entrepreneur over time, we have adopted a more dynamic approach to understand the entrepreneurial process.

The framework presented in Figure 3 shows that the cognitive and affective aspects cannot be dissociated and that their importance in the entrepreneur's decision-making process varies over time. This framework illustrates the environment as a strong influence on the entrepreneur's decisionmaking process. Despite the recognition of its influence, the perspective subjacent to this study is aligned with the premises of the theory of organizational life-cycles (Adizes, 1990; Churchill \& Lewis, 1983; Greiner, 1998; Kelley \& Marram, 2004), which is based on the belief that the entrepreneur assumes a role that is more active than reactive in the development and success of the venture. This reinforces the importance of personal attributes in the entrepreneurial process. 


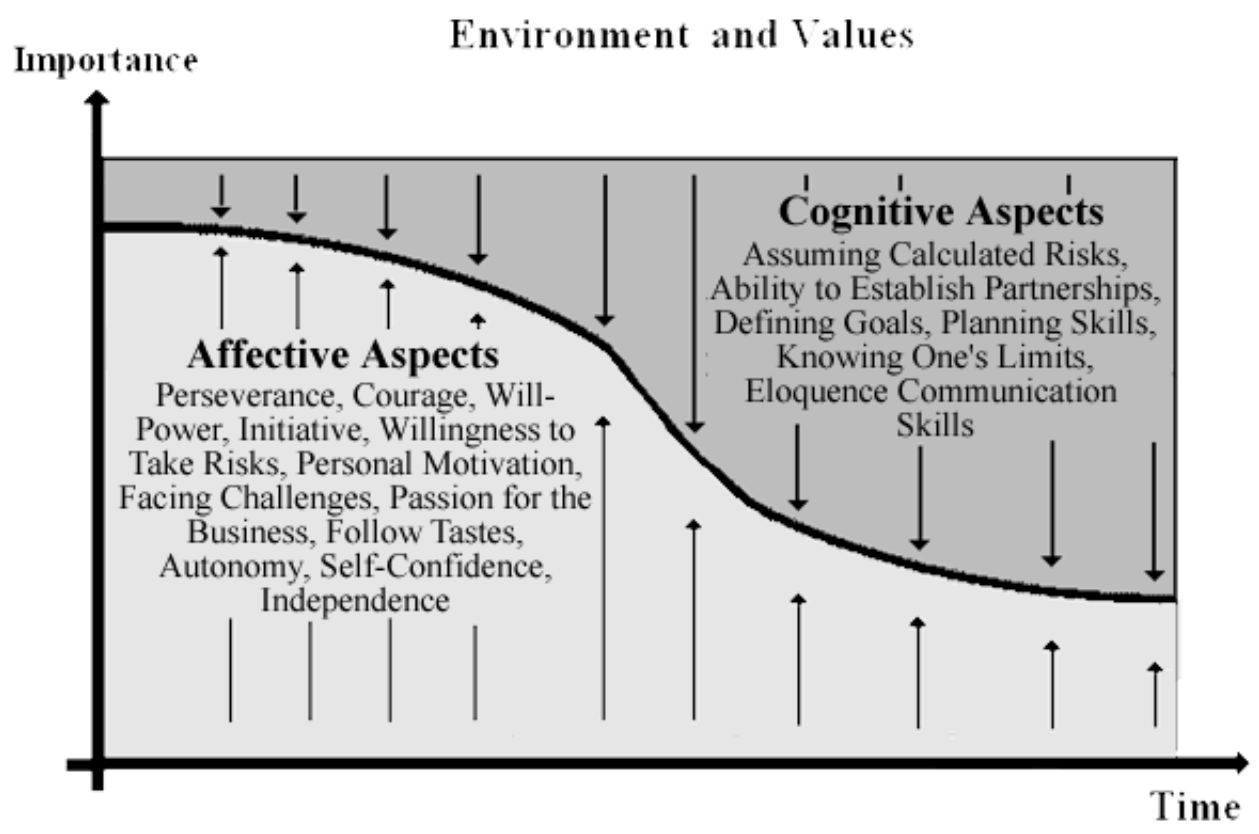

Figure 3 : Entrepreneurial Process Dynamics Framework Source: developed by the authors.

The framework also covers the relation between environment, values and affective and cognitive aspects. According to Elizur et al. (1991), the environment affects values through family, education and religion. Values, in turn, are important factors in understanding the affective and subjective aspects because of their intrinsic relationship with to them.

In short, affective and cognitive aspects change their importance at each stage of the venture development, but we need to emphasize that these environmental factors and entrepreneur values influence the speed of this change. The framework intends to be comprehensive enough to explain these entrepreneurial process dynamics.

\section{REFERENCES}

Adizes, I. (1990). Os ciclos de vida das organizações: como e por que as empresas crescem e morrem e o que fazer a respeito. São Paulo: Ed. Pioneira.

Arenius, P., \& Minniti, M. (2005). Perceptual variables and nascent entrepreneurship. Small Business Economics, 24(3), 233-247.

Barros, F. S. O., \& Moreira, M. V. C. O. (2005, setembro). Comportamento empreendedor e suas implicações: a organização produtiva de micro e pequenas empresas no turismo. Anais do Encontro Nacional da Associação Nacional de Pós-Graduação e Pesquisa em Administração, Brasília, DF, Brasil, 29.

Bastos, A. V. B., \& Borges-Andrade, J. E. (2004). Handbook de estudos organizacionais (Vol. 3). São Paulo: Atlas.

Beugelsdijk, S., \& Noorderhaven, N. (2005). Personality characteristics of self-employed; an empirical study. Small Business Economics, 24(2), 159-167. 
Brazeal, D. V., \& Herbert, T. T. (1999). The genesis of entrepreneurship. Entrepreneurship: Theory \& Practice, 23(3), 29-46.

Bygrave, W. D. (2004). The entrepreneurial process. In W. D. Bygrave \& A. Zacharakis (Eds.). The portable MBA in entrepreneurship. Hoboken, NJ: John Wiley \& Sons.

Carvalho, L. T., Machado, M. C., Silva, N. S., Souza R., \& Ghobril, A. N. (2006, agosto). Atributos dos empreendedores na indústria da moda. Anais do Seminários em Administração FEA-USP, São Paulo, SP, Brazil, 9.

Chay, Y. W. (1993). Social support, individual differences and well-being: a study of small business entrepreneurs and employees. Journal of Occupational and Organizational Psychology, 66(4), 286-303.

Churchill, N. C., \& Lewis, V. L. (1983). The five stages small business growth. Harvard Business Review, 61(3), 30-46.

Clercq, D. de, \& Arenius, P. (2003). Effects of human capital and social capital on entrepreneurial activity. $\quad$ Retrieved $\quad$ April $\quad 15, \quad 2005, \quad$ from http://www.babson.edu/entrep/fer/BABSON2003/VII/VII-P2/VII-P2.html

Cruz, R., Forner, C., \& Libermann, N. M. L. (2003, setembro). Perfil de pequenas empresas brasileiras atendidas pelo Programa Empretec do Sebrae e seus empreendedores. Anais do Encontro Nacional da Associação Nacional de Pós-Graduação e Pesquisa em Administração, Atibaia, SP, Brasil, 27.

Delmar, F., \& Shane, S. (2002, October). What firm founders do: a longitudinal study of the start-up process. Proceedings of the Annual Entrepreneurship, Newton, MA, 22.

Dornelas, J. C. A. (2001). Empreendedorismo: transformando idéias em negócios. Rio de Janeiro: Campus.

Duobiené, J., Gavenas, J., Anskaitis, A., \& Pundziene, A. (2007). Applying indicators of orientation to innovations, potential of growth and strategic objectives to explain corporate entrepreneurship: case study of the three finnish companies. Problems and Perspectives in Management, 5(3), 31-43.

Elizur, D., Borg, I., Hunt, R., \& Beck, I. M. (1991). The structure of work values - A cross cultural comparison. Journal of Organizational Behavior, 12(1), 21-38.

Fernandes, D. V. D. H., \& Santos, C. P. (2008). Orientação empreendedora: um estudo sobre as conseqüências do empreendedorismo nas organizações. RAE Eletrônica, 7(1), 6-34. Retrieved March 12, 2009, from http://www16.fgv.br/rae/eletronica/index.cfm?FuseAction $=$ Artigo\&ID $=4435 \&$ Secao $=$ ARTIGOS \&Volume $=7 \&$ numero $=1 \&$ Ano $=2008$

Filion, L. J. (1999). Diferenças entre sistemas gerenciais de empreendedores e operadores de pequenos negócios. Revista de Administração de Empresas, 39(4), 6-20.

Filion, L. J. (2000). Empreendedorismo e gerenciamento: processos distintos, porém complementares. Revista de Administração de Empresas, 7(3), 2-7.

Fineman, S. (2001). An emotion agenda. In S. Fineman (Ed.). Emotion in organizations (pp. 216-224). Londres: Sage.

Gersick, K. E. (1997). De geração para geração: ciclos de vida das empresas familiares. São Paulo: Negócio Editora.

Gimenez, F. A. P. (2000, outubro). O estrategista na pequena empresa. Anais do Encontro de Estudos sobre Empreendedorismo e Gestão de Pequenas Empresas, Maringá, PR, Brazil, 1. 
Greiner, L. E. (1998). Revolution as organizations grow. Harvard Business Review, 76(3), 55-66.

Hannan, M. T., \& Freeman, J. (1989). Organizational ecology. Cambridge, MA: Harvard Business Press.

Hornaday, J. A., \& Aboud, J. (1971). Characteristics of successful entrepreneurs. Personnel Psychology, 24(2), 141-153.

Kelley, D., \& Marram, E. (2004). Managing a growing business. In Bygrave, W. D. \& Zacharakis, A. (Eds.). The portable MBA in Entrepreneurship (pp. 405-426). Hoboken, NJ: John Wiley \& Sons.

Lenzi F. C., Venturi, J. L., \& Dutra, I. S. (2005, setembro). Estudo comparativo das características e tipos de empreendedores em pequenas empresas. Anais do Encontro Nacional da Associação Nacional de Pós-Graduação e Pesquisa em Administração, Brasília, DF, Brasil, 29.

Lindsay, N. J. (2005). Toward a cultural model of indigenous entrepreneurial attitude. Academy of Marketing Science Review, 9(2), 118.

Machado-da-Silva, C. L., \& Fonseca, V. S. (1999). Competitividade organizacional: uma tentativa de reconstrução analítica. Organizações e Sociedade, 4(7), 97-114.

Mallmann, T. D. M., Borba, B. W., \& Ruppenthal, J. E. (2005, setembro). Avaliação da tipologia dos empreendedores residentes de incubadoras utilizando o teste "Keirsey Temperament Sorter". Anais do Encontro Nacional da Associação Nacional de Pós-Graduação e Pesquisa em Administração, Brasília, DF, Brasil, 29.

Mcclelland, D. (1965). Achievement motivation can be developed. Harvard Business Review, 43(6), 178-188.

Mayer, R. C., Davis, J. H., \& Schoorman, F. D. (1995). An integration model of organizational trust. Academy of Management. The Academy of Management Review, 20(3), 709-734.

Miner, J. B. (1998, October). Evidence for the existence of a set of personality types, defined by psychological tests, that predict entrepreneurial success. Proceedings of the Eighteenth Annual Entrepreneurship Research Conference, Newton, MA, USA.

Mitchell, R. K., Busenitz, L., Lant, T., McDougall, P. P., Morse, E. A., \& Smith, B. (2002). Toward a theory of entrepreneurial cognition: rethinking the people side of entrepreneurship research. Entrepreneuship Theory \& Practice, 27(2), 93-104.

Nassif, V. M. J., Ghobril, A. N., Castilho, A. F., Silva, N. S., \& Guardani, F. R. (2004, setembro). Contribuição para o entendimento das competências do empreendedor: a derivação de um esquema a partir de relatos de trajetórias empresariais em pequenas empresas. Anais do Encontro Nacional da Associação Nacional de Pós-Graduação e Pesquisa em Administração, Curitiba, PR, Brazil.

Petrakis, P. E. (2005). Risk perception, risk propensity and entrepreneurial behaviour: the greek case. Journal of American Academy of Business, 7(1), 233242.

Porter, M. E. (1980). Competitive strategy: techniques for analyzing industries and competitors. New York: Free Press.

Rokeach, M. (1973). The nature of human values. New York: Free Press.

Sadler-Smith, E., Hampson, Y., Chaston, I., \& Badger, B. (2003). Managerial behavior, entrepreneurial style, and small firm performance. Journal of Small Business Management, 41(1), 47-67. 
Salim, C. S. (2004). Administração empreendedora: teoria e prática usando estudos de casos. Rio de Janeiro: Campus.

Schumpeter, J. A. (1984). Teoria do desenvolvimento econômico. São Paulo: Abril Cultural.

Schwartz, S. H. (1994). Are there universal aspects in the structure and contents of human values? Journal of Social Issues, 50(4), 19-45.

Schwartz, S. H., \& Sagiv, L. (1995). Identifying culture-specifics in the content and structure of values. Journal of Cross-Cultural Psychology, 26(1), 92-116.

Serviço Brasileiro de Apoio às Micro e Pequenas Empresas. (2005a). Boletim estatístico das micro e pequenas empresas. Principais resultados (IBGE/CEMPRE). Retrieved April 21, 2006 from http://www.sebrae.com.br/br/mpe_numeros/sub_principais_est.asp

Serviço Brasileiro de Apoio às Micro e Pequenas Empresas. (2005b). Boletim estatístico das micro e pequenas empresas. Retrieved April 21, 2006 from http://www.dce.sebrae.com.br/bte/bte.nsf/03DE0485DB219CDE0325701B004CBD01/\$File/N T000A8E66.pdf

Serviço Brasileiro de Apoio às Micro e Pequenas Empresas. (2005c). Sobrevivência e mortalidade das empresas paulistas de 1 a 5 anos (versão 2004/05). Retrieved April 21, 2006 from http://www.sebraesp.com.br/principal/conhecendo\%20a\%20mpe/mortalidade\%20de\%20empres as/sobr_mortalidade_versao_2004_2005.aspx

Tenbrunsel, A. E., Galvin, T. L., Neale, M. A., \& Bazerman, M. H. (2004). Cognições em organização. In Clegg, S., Hardy, C., Nord, W., Caldas, M., Fachin, R., Fischer, T. (Orgs.). Handbook de estudos organizacionais. (Vol. 3, pp. 33-68). São Paulo: Atlas.

Thompson, J. L. (2004). The facets of the entrepreneur: identifying entrepreneurial potential. Management Decision, 42(1/2), 243-258.

Timmons, J. A. (1978). Characteritics and role demands of entrepreneurship. American Journal of Small Business, 3(1), 5-17.

Ucbasaran, D., Westhead, P., \& Wright, M. (2001). The focus of entrepreneurial research: contextual and process issues. Entrepreneurship Theory \& Practice, 25(4), 57-80.

Westhead, P., Ucbasaran, D., \& Wright, M. (2005). Decisions, actions, and performance: do novice, serial, and portfolio entrepreneurs differ? Journal of Small Business Management, 43(4), 393-417. 